Zakharova V. ${ }^{1}$, MD, PhD, Head of the Department of Pathology and Pathological Anatomy, https://orcid.org/00000003-3139-0366

Savchuk T.2 , PhD, Associate Professor of the Department of Pathological Anatomy No. 2, https://orcid.org/00000002-7218-0253

Truba Ya. ${ }^{1}$, PhD, Head of the Department of Surgical Treatment of Congenital Heart Diseases in Newborns and Young Children, https://orcid.org/0000-0001-5214-408X

Lazoryshynets V. ${ }^{1}$, MD, PhD, Academician, Director of State Institute, https://orcid.org/0000-0002-1748-561X

Rudenko 0.1 PhD, Leading Researcher of Department of Pathology and Pathological Anatomy, https://orcid. org/0000-0003-3640-566X

${ }^{1}$ National Amosov Institute of Cardiovascular Surgery of the National Academy of Medical Sciences of Ukraine, Kyiv, Ukraine

${ }^{2}$ Bogomolets National Medical University, Kyiv, Ukraine

\title{
Hypoplastic Left Heart Syndrome: Prognostic Significance of Morphological Variants of the Heart in the Choice of Treatment Approach
}

\begin{abstract}
Hypoplastic left heart syndrome (HLHS) is one of the most complicated congenital heart defects which leads to the inevitable fatal outcome in the natural course of the disease. Currently, Norwood procedure and fetal aortic valvuloplasty are considered the major approaches for surgical treatment of HLHS. However, the prognosis of such surgeries is often unpredictable.

The aim. To study morphological variations of the left ventricle (LV) in HLHS and evaluate the prognostic significance of each of them in the choice of surgical approach.

Materials. The main group included 63 hearts of newborns with HLHS, the comparison group included 53 hearts of newborns without cardiac pathology.

Methods. The methods used were survey microscopy, as well as macro- and micromorphometry of various parameters of the heart, calculation of the ratio of their absolute values (indices) with subsequent statistical data processing.

Results. Five types of LV were identified in HLHS patients based on the size and shape of the cavity, wall thickness, presence or absence of fibroelastosis: slit-like hypoplastic (Type I) $(\mathrm{n}=10 ; 15.9 \%)$; slit-like hypertrophic (Type II) (n = 19; 30.2\%); cylindrical (Type III) ( $=22 ; 34.9 \%)$; lacunar (Type IV) $(n=6 ; 9.5 \%$ ); lacunar-cylindrical (Type V) ( $\mathrm{n}=6$; 9.5\%). In Type I left ventricles, the interventricular index (IVI) (the ratio of the areas of the free walls of the left and right ventricles on the cross sections of the heart) was the smallest: $0.13 \pm 0.03$ units versus normal $1.96 \pm 0.31$ units. In Type II left ventricles, the value was equal to $1.69 \pm 0.23$ units; in Type III it was $1.59 \pm$ 0.64 units; in Type IV it was $1.31 \pm 0.03$ units; in Type V it was $1.05 \pm 0.52$ units. The index of the working area of the right ventricular myocardium (RVI) (the ratio of the area of the free wall of the right ventricle to the sum of the areas of the free wall and interventricular septum) in Type I LV was the highest: $81.3 \pm 5.7 \%$ versus normal $57.1 \pm$ 2.02\%; in Type II it was $49.7 \pm 6.4 \%$; in Type III it was $39.8 \pm 2.9 \%$; in Type IV it was $69.7 \pm 16.1 \%$; in Type V it was $41.3 \pm 24.4 \%$.Type III-V LVs have always been associated with fibroelastosis, in contrast to Type I and II LVs.

Conclusions. In HLHS, Type I hearts are the most eligible for the Norwood procedure, since the LV, due to its minimal size, is not an excess ballast for the working right ventricle. Type II LV is optimal for the fetal aortic valvuloplasty, since during the II-III trimesters of gestation they can join the circulatory system due to remodeling. HLHS with LV fibroelastosis (Types III, IV, V) seem to be the least favorable for both pre- and postnatal surgery, especially in the presence of fibroelastosis of the right ventricle.
\end{abstract}

Keywords: congenital heart disease, hypoplastic left heart syndrome, morphological variations of the left ventricle, the variations of valvular pathology, surgical approach. 
Introduction. Hypoplastic left heart syndrome (HLHS) is a severe congenital malformation which includes aortic valve atresia (AA) or pronounced hypoplasia of aortic root, or aortic valve stenosis (AS) combined with hypoplasia of ascending aorta and congenital malformations of the left ventricle combined with mitral valve stenosis (MS) or mitral valve atresia (MA) [1]. This pathology occurs in $0.5-8 \%$ of all congenital heart defects [2]. The etiology of HLHS remains unclear to date, and genetic, infectious, autoimmune factors as the cause of the diseases are being discussed [3]. Without surgical treatment the patients' mortality rate is $100 \%[4,5,16]$. HLHS is diagnosed in $40-85 \%$ of cases during prenatal development $[6,7]$. Pregnant women management protocol suggests routine ultrasound examination from pregnancy week 18, when congenital disorders of the fetus may be identified. In case of HLHS identification the issue of treatment approach is being resolved: to terminate pregnancy, to perform fetal aortic valvuloplasty or to continue pregnancy with subsequent surgical correction in neonatal period.

Surgical correction of the malformation is complicated and multistage. The first stage is the Norwood procedure, as a result of which all hemodynamic is provided by right ventricle (RV) only, and left ventricle (LV) is a ballast mass for the working RV. The RV often demonstrates a progressive failure after the Norwood procedure $[8,11]$. The five-year survival rate in patients undergoing multistage surgical correction is accounted for $61 \%$ [19].

Restoration of biventricular circulation would be the best way to reconstruct the heart in HLHS. During embryogenesis, myocardium is capable of high proliferative activity. Therefore, after restoration of intracardiac hemodynamics at this stage, the growth of hypoplastic LV structures is possible $[9,10]$. Consequently, since 2000 , attempts have been made for prenatal correction of HLHS, namely, surgical removal of the stenosis of aortic valves (AV) (fetal aortic valvuloplasty) $[11,12]$. However,

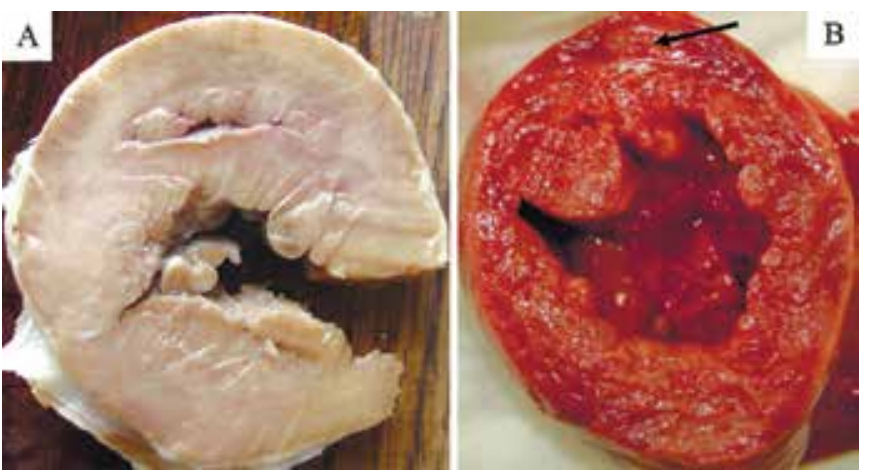

Fig. 1. Macro specimens. Cross sections of hearts with HLHS. $L V$ slit-like cavities. A - with hypertrophy of the wall, $B$ - with hypoplasia of the wall (the arrow indicates the LV cavity). not all cases of intrauterine intervention led to a positive outcome [13]. Hypothetically, the success depends on the state of the LV. [14]. Notably, few publications with detailed morphological study of the LV in HLHS have been found $[15,16,17]$.

The aim. To study the different types of LV structure in HLHS and to substantiate the most favorable treatment approach for each of them (Norwood procedure, fetal aortic valvuloplasty or symptomatic treatment).

Material and methods. The hearts of 63 newborns with HLHS and 53 hearts of control group have been studied. The material was obtained from the Department of Pathological Anatomy of Amosov National Institute of Cardiovascular Surgery, as well as from the Okhmatdyt Department of Pediatric Pathomorphology in the period from 2010 to 2016. Histological methods, computer reconstruction of serial histological sections, macro- and micromorphometry (absolute indicators and their ratio: special morphometric indexes) that can be used for ultrasonography have been applied. In particular, interventricular index (IVI) was calculated. For this purpose, the histological cross sections of the medial portion of the heart have been analyzed using the OLYMPUS BX41 microscope equipped with OLYMPUS DP21 camera, and cellSens Dimension software to measure the areas of free walls (without the interventricular septum) of the left and right ventricles and calculated their ratio. In addition, the percentage of the area of the free wall of the RV to the sum of the areas of the free wall of the RV and the interventricular septum (IVS) was calculated.

Results. The analysis of the macro specimens has shown that in HLHS the apex of the heart was formed by the RV: the length of the heart did not differ significantly from the controls $(3.59 \pm 0.29 \mathrm{~cm}$ versus normal $3.71 \pm$ $0.38 \mathrm{~cm}$ ), while the length of the LV was significantly shorter than that of the normal one $(1.89 \pm 0.82 \mathrm{~cm}$ versus $3.71 \pm 0.37 \mathrm{~cm}$, respectively) ( $\mathrm{p} \leq 0.05$ ). Notably, polymorphism of the LV cavity was significant. It was very narrow, slit-like $(n=29)$ (Fig. 1).

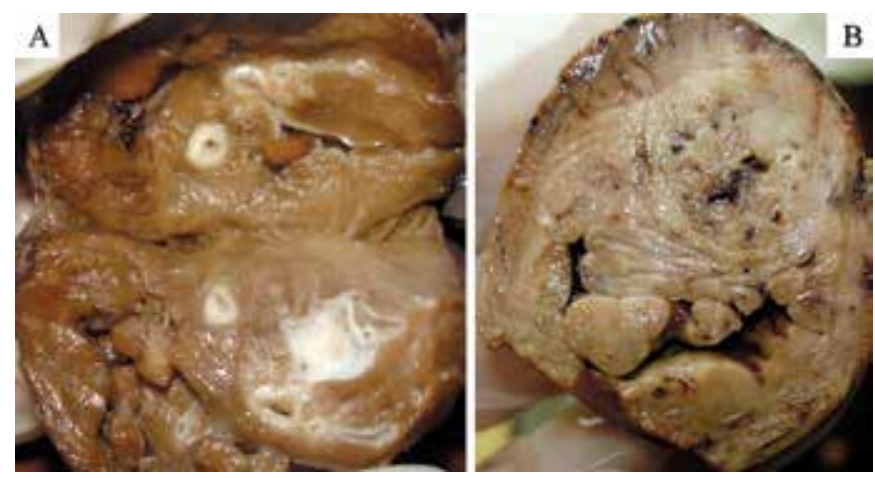

Fig. 2. Macro specimens. Cross sections of hearts with HLHS. Variations of the lacunar structure of the $L V$ cavity $(A, B)$. 

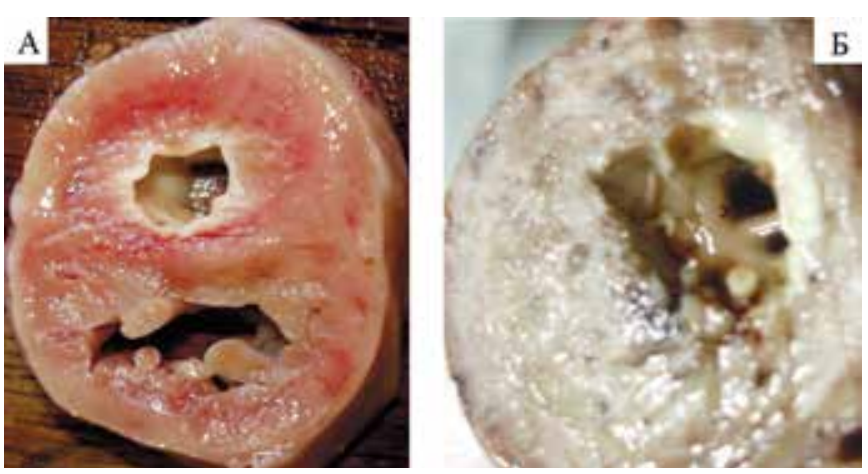

Fig. 3. Macro specimens. Cross sections of hearts with HLHS. A cylindrical shape of the LV cavity. B - lacunar-cylindrical shape of the LV cavity. Numerous atypical muscular septa (trabeculae) were located across the lumen.

In 6 hearts, the LV lumen was almost completely filled with myocardial mass, pierced by narrow twisted canals, and on the cross sections looked like lacunae (Fig. 2).

In 22 patients, the shape of the LV cavity was almost cylindrical (Fig. 3A). Six observations showed numerous peculiar muscular septa across the lumen of the apical portion of the left ventricle which reduced the effective size of its cavity. At the base of such hearts, the LV cavity was enlarged; as a result, the ventricle had a mixed lacunarcylindrical shape (Fig. 3B).

The LVs with slit-like cavities differed from each other in the thickness of the myocardium: it was either hypertrophied (Fig. 1A) or hypoplastic (Fig. 1B).

These two main features (features of the LV cavity and the thickness of its walls) formed the basis for classification of the LV in HLHS into 5 types: slit-like hypoplastic (Type I) $(\mathrm{n}=10 ; 15.9 \%) ;$ slit-like hypertrophic (Type II) ( $\mathrm{n}=19 ; 30.2 \%)$; cylindrical (Type III) ( $\mathrm{n}=22 ; 34.9 \%)$; lacunar (Type IV) ( $=6$; 9.5\% ); lacunar-cylindrical (Type V) $(\mathrm{n}=6$; 9.5\%). Type III-V LVs have always been associated with fibroelastosis, in contrast to LVs of Type I and II.
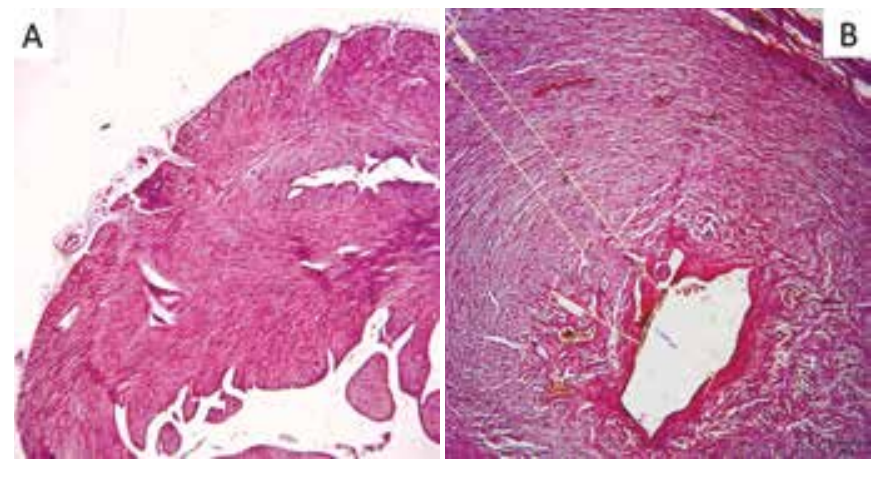

Fig. 4. Microspecimens (computer reconstruction of cross sections of hearts with HLHS). A - slit-like hypoplastic type of $L V ; B$ - cylindrical type of $L V$.

Histological study of the specimens has shown that the architectonics of the myocardium of the LVs of the first three types did not differ significantly from the normal LVs. The differences were only in the thickness of the layers of the ventricles of Type I and II, as well as in the presence of fibroelastosis in Type III ventricles (Fig. 4). In LV of Type IV, the compact layer of the myocardium was dramatically thinned, and in some places it was not detected at all. Most of the histological sections were occupied by chaotically oriented bundles of muscle fibers, between which small irregular lumens were visualized, covered with fibrous tissue (Fig. 5A). The basal part of the LV of Type $\mathrm{V}$ was similar to Type III with pronounced fibroelastosis. In the apical portion of the Type $V$ ventricles, fibroelastosis was less pronounced, but the myocardium retained a structure almost similar to embryonic structure with the absence of full stratification and with numerous trabeculae, crossing the ventricular lumen (Fig. 5B). Of 34 hearts affected by fibroelastosis (Types III, IV, V), the signs of antenatal inflammation were revealed in the myocardium in 25 cases (73.5\%), namely, fibrosis, calcification (Fig. 6A) and fine
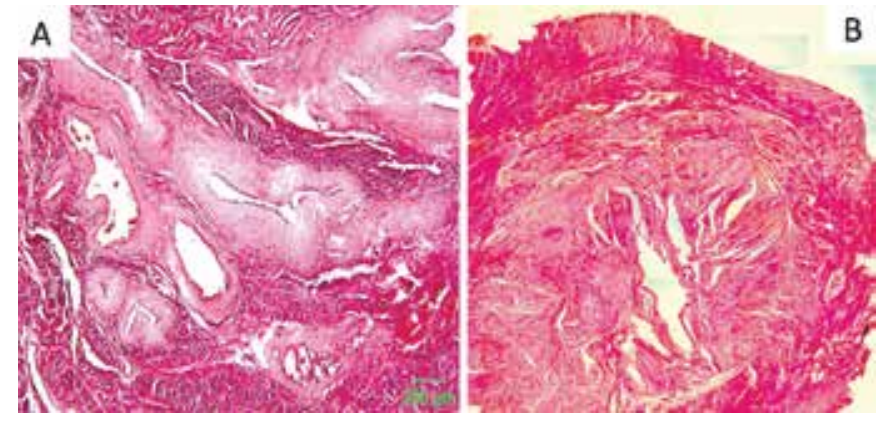

Fig. 5. Microspecimens (computer reconstruction of cross sections of hearts with HLHS). A - lacunar type of $L V$; $B$ - lacunar-cylindrical type of LV (apical part).

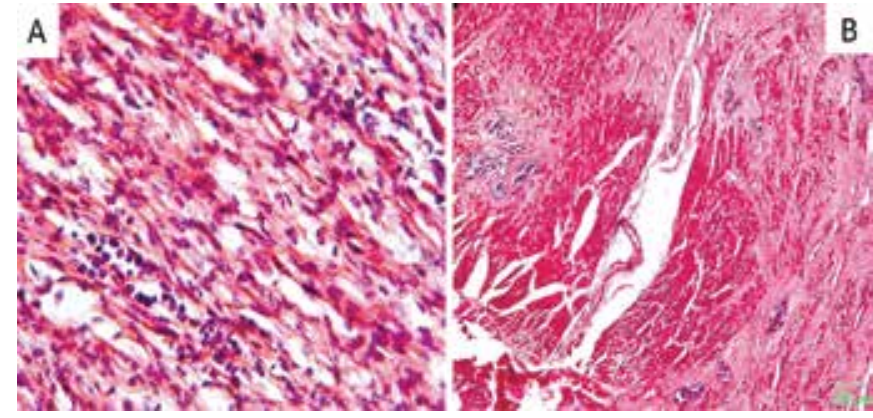

Fig. 6. Microspecimens of hearts with HLHS. A - fine lymphoid infiltrates in the $L V$ of the cylindrical type; $B$ - fibrosis and calcifications in the LV of the lacunar-cylindrical type. $\times 40$ magnification; H\&E stain. 


\section{Table 1}

Diameters of the AV and MV of the hearts of newborns with HLHS in different types of the LV and in comparison group

\begin{tabular}{|c|c|c|c|c|c|c|}
\hline \multirow[b]{2}{*}{ Valves (diameter), cm } & \multicolumn{5}{|c|}{ Types of the left ventricles in HLHS } & \multirow{2}{*}{$\begin{array}{l}\text { Comparison } \\
\text { group }(n=53)\end{array}$} \\
\hline & $I(n=10)$ & II (n=19) & III $(n=22)$ & IV $(n=6)$ & $V(n=6)$ & \\
\hline MV & 0 & $0.63 \pm 0.14^{*}$ & $0.36 \pm 0.07^{*}$ & $0.2 \pm 0.05^{*}$ & $0.5 \pm 0.06^{*}$ & $0.89 \pm 0.24$ \\
\hline AV & 0 & $0.06 \pm 0.03^{*}$ & $0.06 \pm 0.02 *$ & 0 & $0.05 \pm 0.01^{*}$ & $0.71 \pm 0.19$ \\
\hline
\end{tabular}

* The difference is significant compared to the normal values at ( $\mathrm{p} \leq 0.05), 0$ - atresia.

lymphoid infiltrates (Fig. 6B). The above changes were not found in any of the first two types of the LV.

The quantitative study of the size of the valve orifices of the hearts of newborns has found that in all hearts of the Group I, both the mitral (MV) and aortic (AV) valves were in a state of atresia (Table 1).

The sizes of the AV orifices in all groups were minimal $(0.05-0.06 \pm 0.01 \mathrm{~cm})$ or atresic. The sizes of the MV were always significantly smaller than normal, but varied in the groups. The smallest MV sizes $(0.2 \pm 0.05 \mathrm{~cm})$ were in the lacunar cavities of the LV; the largest $(0.63 \pm 0.14$ $\mathrm{cm}$ ) sizes were in the slit-like cavity in combination with hypertrophied LV walls. The MV diameter was $0.5 \pm 0.06$ $\mathrm{cm}$ in lacunar-cylindrical LV and $0.36 \pm 0.07 \mathrm{~cm}$ in cylindrical LV. The above data indicate a significant effect of MV size on $\mathrm{LV}$ formation and, possibly, on the sizes of the $\mathrm{AV}$ and ascending aorta.

Notwithstanding that the length of the left ventricle in HLHS has always been reduced compared to the normal values, the hypertrophied walls of a functionally defective LV can be a significant burden for the working RV. To assess the degree of this load, on the cross sections of the medial part of the heart the areas of the myocardium of the left and right ventricles (without the IVS) were measured and their ratio was calculated (IVI). In addition, another indicator, namely, the index of the working area of the right ventricle (RVI) (the percentage of the area of the free wall of the RV to the sum of the areas of the free wall and IVS), which is more convenient for measurement, have been analyzed. These indicators can be used in the clinic for echocardiography.
The findings of morphometric studies of the myocardium are shown in Table 2.

The measurement of the areas of the myocardium of the ventricles of the medial parts of the hearts in the comparison group has shown that on the cross sections the IVI value was $1.96 \pm 0.3$ units, that is, the average size of the LV myocardium was almost twice greater than that of the RV. In HLHS, this index in Type I LV was $0.13 \pm 0.03$ units, which indicated a significant predominance of the area of the RV myocardium over the left ventricle. In all other groups, the area of the cross section of the myocardium of the hypoplastic LV to some extent prevailed over the area of the RV myocardium: In Type II left ventricles the IVI value was equal to $1.69 \pm 0.23$ units; in Type III it was $1.59 \pm 0.64$ units; in the lacunar type it was $1.31 \pm 0.03$ units; in Type $V$ it was $1.05 \pm 0.52$ units. In Type II and III $\mathrm{LV}$, the ratio of the areas of the LV and RV was the highest. However, in type III, the LV cavity was covered with a thick layer of fibrous tissue which limited its ability to remodeling. At the same time, the structure of the Type II LV myocardium predicted that in optimal fetal aortic valvuloplasty at II-III trimesters of gestation the LV will be able to remodeling and can join the circulatory system.

In the comparison group, the RVI value was $57.1 \pm$ $0.02 \%$. In the most pronounced LV hypoplasia (Group I), when the IVS size was small due to the small LV size, the RVI was significantly higher than that of the normal heart $(81.3 \pm 5.7 \%)$. In the lacunar type of the $\mathrm{LV}$, the free wall of the RV was $69.7 \pm 16.1 \%$ of the total area of the $\mathrm{RV}$ myocardium. This is due to the fact that the Type IV LV had a short length at the greatest width. In Group II

\section{Table 2}

Values of the IVI and RVI indices for hearts in the medial part of the left ventricle in all groups with HLHS compared to normal values

Types of the LV

\begin{tabular}{lcccccc}
\cline { 2 - 6 } Indices & $\begin{array}{c}\text { Comparison } \\
\text { group }\end{array}$ & I & II & III & IV & V \\
\hline $\mathrm{IVI}$ & $1.96 \pm 0.31$ & $0.13 \pm 0.03^{*}$ & $1.69 \pm 0.3$ & $1.59 \pm 0.64^{*}$ & $1.31 \pm 0.03^{*}$ & $1.05 \pm 0.52^{*}$ \\
\hline $\mathrm{RVI}$ & $57.1 \pm 2.02$ & $81.3 \pm 5.7^{*}$ & $49.7 \pm 6.4$ & $39.8 \pm 2.9^{*}$ & $69.7 \pm 16.1^{*}$
\end{tabular}

* The difference is significant compared to the normal values at $(\mathrm{p} \leq 0.05)$. 
hearts, the RVI did not significantly differ from the normal ones; in the ventricles of the cylindrical and lacunarcylindrical types it was significantly lower than the control values. This is due to the prominent IVS hypertrophy which overcomes LV resistance with an increased mass of the trabecular (lacunar type) or compact (cylindrical type) myocardium.

Discussion. The left ventricle of the heart implements a systolic ejection of blood into the aorta due to the movement of its myocardium along a very complex trajectory. At the end of the diastole, the basal segments of the LV wall begin to move along the longitudinal axis towards the apex and, simultaneously, rotate clockwise. The apical segments move almost along the longitudinal axis, though rotate counterclockwise. Due to these multidirectional circular bases and apex, the central part of the LV is compressed towards the center, and the entire myocardium twists, providing optimal cardiac output with the lowest energy costs [18]. The basis of the high functional efficiency of the myocardium is a strict anatomical and histological organization [19]. Muscle fibers, united into a single threedimensional "functional syncytium" in each segment have their own specific orientation which defines the trajectory of movement of the segment. However, direction, in which the segment will move along a given trajectory, depends on the sequence of excitation and contraction of cardiomyocytes (CMC). The contracted CMC is the fulcrum to which the next contracting myocyte is pulled, defining the direction of movement of the segment together with adjacent fibers. Normally, excitation through the cardiac conduction system is transmitted primarily to the subendocardial myocardium, i.e. into trabeculae. CMC bundles of the inner layer of the compact myocardium are connected to them, each fragment of which, during systole, shifts towards the corresponding trabecula. Thus, the non-compact layer of the myocardium plays an important role in the functioning of the heart chambers.

In HLHS, the hearts with pronounced signs of dysplasia, in which the architectonics of both the compact and, especially, the trabecular layer is damaged, are common. There were $12(19 \%)$ such hearts in our material: 6 with LV of the lacunar type and 6 hearts of the lacunar-cylindrical type. Such LV, even in a hypothetical restoration of transmural and transaortic blood flow, would not be able to provide full cardiac output. Therefore, fetal aortic valvuloplasty was not indicated for patients of these two groups, since, additionally, their AV was either atresic (Type IV) or had a microscopic punctiform orifice (Type V). Due to hyperplasia of the trabecular apparatus of the left ventricle, the area of the myocardium on the cross sections of the left and right ventricles was almost the same. IVS was $1.3 \pm 0.01$ units for Type IV, $1.05 \pm 0.5$ units for Type $V$.

The RVI was more dependent on the size of the IVS. In Type IV LV, the value of the RVI was greater than that in the comparison group $(69.7 \pm 16 \%$ versus $57.1 \pm 2.0 \%$ ). This is explained by the fact that the LV of the lacunar type was of small size and orbicular with a very short length of the IVS. The AV atresia in the presence of a minimal orifice on the MV $(0.2 \pm 0.05 \mathrm{~cm})$ caused gradual overload of the ventricle with remodeling of its shape. We hypothesize that HLHS with Type IV LV has a good prognosis in Norwood procedure, if fibroelastosis, which is always present in this type of $\mathrm{LV}$, does not also affect the RV. Type V LV was larger and elongated in contrast to Type IV LV, since the diameter of its MV was larger $(0.5 \pm$ $0.06)$ with a punctiform orifice on the AV. Therefore, the index of the working area of the RV in such hearts was reduced to $41.3 \pm 24 \%$, indicating an increase in the load on the myocardium of the working $\mathrm{RV}$ with a limitation of its compensatory capabilities.

The cylindrical LV (Type III) differs from the LV of Type IV and $\mathrm{V}$ in architectonics of its muscle fibers that corresponded to the normal structure of the myocardium. The average size of the MV and $\mathrm{AV}$ orifices in this group is $0.36 \pm 0.01 \mathrm{~cm}$ and $0.06 \pm 0.01 \mathrm{~cm}$, respectively. The shear section of the free wall of the Type III LV was $1.59 \pm 0.6$ times higher than the similar value of the RV (in control group it was $1.96 \pm 0.3$ times higher). The area of the free walls of the RV accounted for $38.8 \pm 2.9 \%$ of the sum of the areas of the free walls and the IVS (in the comparison group it was $57.1 \pm 2.0$ ).

Thus, Type III LV with its complete surgical exclusion from the bloodstream in the postnatal period will be a significant ballast for the RV, worsening the prognosis of the surgery. It is risky to perform fetal aortic valvuloplasty in Type III LV due to pronounced fibroelastosis, and signs of inflammation are often (72\%) found.

In HLHS, the hearts with Type I (slit-like hypoplastic) LV are the most optimal for Norwood procedure. The ventricles of the above type have the adequate structure of the myocardium, without fibroelastosis and inflammation, though with complete blockage of transventricular blood flow, caused by atresia of both mitral and aortic valves. The lack of functional load resulted in undeveloped structures of the ventricle, and it had the appearance of a small muscular inclusion with a slit-like cavity in the basal part of the left wall of the single RV. The IVI in Type I LV was $0.13 \pm$ 0.01 versus normal $1.96 \pm 0.3$. Due to the minimal size of the IVS, the RVI exceeded the control values: $81.3 \pm 5.7 \%$ and $57.1 \pm 2.0 \%$, respectively. The duration and quality of life of patients after Norwood procedure with minimal LV will depend only on the compensatory capabilities of the $\mathrm{RV}$ which works for both circulations, without additional load in the form of a ballast LV.

In HLHS the fetal aortic valvuloplasty is, probably, the most effective in Type II LV malformation. It is characterized by: a normally formed myocardium, the largest LV MV out of all types $(0.63 \pm 0.1 \mathrm{~cm})$, the presence of a punctiform orifice on the $\mathrm{AV}$, the absence of fibroelas- 
tosis and signs of inflammation, the highest value of the IVI $(1.69 \pm 0.1 \mathrm{~cm})$ and almost normal value of the RVI $(49.7 \pm 6.4$ versus $57.1 \pm 2.0)$. Enlargement of the $\mathrm{AV}$ in the first trimester of pregnancy will increase the LV function during the period when proliferative capabilities of the myocardium are still very high, and it will be able to remodeling and be more fully involved in the circulatory system.

Conclusions. In HLHS, Type I hearts are the most eligible for the Norwood procedure, since the LV, due to its minimal size, is not an excess ballast for the working right ventricle. Type II LV is optimal for the fetal aortic valvuloplasty, since during the II-III trimesters of gestation they have the ability to remodeling and can join the circulatory system. HLHS with LV fibroelastosis (Types III, IV, V) seem to be the least favorable for both pre- and postnatal surgery, especially in the presence of fibroelastosis of the right ventricle.

\section{References}

1. Vogel M, McElhinney DB, Wilkins-Haug LE, Marshall AC, Benson CB, Juraszek AL, et al. Aortic stenosis and severe mitral regurgitation in the fetus resulting in giant left atrium and hydrops: pathophysiology, outcomes, and preliminary experience with pre-natal cardiac intervention. J Am. Coll. Cardiol. 2011;57:348-355. https://doi. org/10.1016/j.jacc.2010.08.636

2. Allan LD, Sharland G, Tynan MJ. The natural history of the hypoplastic left heart syndrome. Int. J. Cardiol. 1989;25(3):341-343. https://doi.org/10.1016/01675273(89)90226-x

3. Cole CR, Yutzey KE, Brar AK, Goessling LS, Van VickleChavez SJ, Cunningham MW, et al. Congenital Heart Disease Linked to Maternal Autoimmunity against Cardiac Myosin. The Journal of Immunology. 2014;192(9):40744082. https://doi.org/10.4049/jimmunol.1301264

4. Hoffman J, Kaplan S, Liberthson R. Prevalence of congenital heart disease. Am Heart J. 2004;147(3):425-439. https://doi.org/10.1016/j.ahj.2003.05.003

5. Lee MG, Brizard CP, Galati JC, Iyengar AJ, Rakhra SS, Konstantinov IE, et al. Outcomes of patients born with single-ventricle physiology and aortic arch obstruction: the 26-year Melbourne experience. J. Thorac. Cardiovasc. Surg. 2014;148(1):194-201. https://doi.org/10.1016/j. jtcvs.2013.07.076

6. Ahmed B, Stanojevic M, Kopjar T. Accuracy of the fetal echocardiography in the high risk pregnancies. Donald School. J. Obstetr. Gynecol. 2007;1(1):86-95. https://doi. org/10.5005/jp-journals-10009-1088

7. Chew C, Halliday JL, Riley MM, Penny DJ. Population-based study of antenatal detection of congenital heart disease by ultrasound examination. Ultrasound Obstet. Gynecol. 2007;29(6):619-624. https://doi.org/10.1002/uog.4023

8. Honjo 0 , Caldarone CA. Hybrid palliation for neonates with hypoplastic left heart syndrome: current strategies and outcomes. Korean Circ J. 2010;40(3):103-111. https://doi.org/10.4070/kcj.2010.40.3.103

9. Grossfeld P. Hypoplastic left heart syndrome: new insights. Circulation Research. 2007;100(9):1246-1248. https://doi.org/10.1161/01.RES.0000268192.20525.c2

10. Hasan BS, Keane JF, Tworetzky W, Lock JE, Marshall AC. Postnatal angiographic appearance of left ventricular myocardium in fetal patients with aortic stenosis having in-utero aortic valvuloplasty. Am. J. Cardiol. 2009;104(9):1271-1275. https://doi.org/10.1016/j. amjcard.2009.06.044

11. Wilkins-Haug LE, Tworetzky W, Benson CB, Marshall AC, Jennings RW, Lock JE. Factors affecting technical success of fetal aortic valve dilation. Ultrasound Obstet. Gynecol. 2006;28(1):47-52. https://doi.org/10.1002/uog.2732

12. Pedra SR, Peralta CF, Crema L, Jatene IB, da Costa RN, Pedra CA. Fetal interventions for congenital heart disease in Brazil. Pediatr Cardiol. 2014;35(3):399-405. https:// doi.org/10.1007/s00246-013-0792-3

13. Hraška V, Sinzobahamvya N, Haun C, Photiadis J, Arenz C, Schneider M, et al. The long-term outcome of open valvotomy for critical aortic stenosis in neonates. The Annals of Thoracic Surgery. 2012;94(5):1519-1526. https://doi. org/10.1016/j.athoracsur.2012.03.056

14. Simpson JM, Sharland GK. Natural history and outcome of aortic stenosis diagnosed prenatally. Heart. 1997;77(3):205-210. https://doi.org/10.1136/ hrt.77.3.205

15. Axt-Fliedner R, Kreiselmaier P, Schwarze A, Krapp M, Gembruch U. Development of hypoplastic left heart syndrome after diagnosis of aortic stenosis in the first trimester by early echocardiography. Ultrasound Obstet. Gynecol. 2006;28(1):106-109. https://doi.org/10.1002/ uog. 2824

16. Zakharova V, Savchuk T, Rudenko O. Hypoplastic left heart syndrome: Structural changes of the left ventricular myocardium. Virchows Arch. 2013;463(2):198.

17. Savchuk T. [Hypoplastic left heart syndrome: Morphogenesis of patomorphological types of the left ventricle]. Georgian Medical News. 2020;2(229):55-61. Russian. PMID: 32242845

18. Trembovetska OM, Knyshov GV, Zakharova VP, Rudenko OV, Moroz MM. [Dynamic characteristics morphological background of the heart left ventricle myocardium]. Heart and vessels. 2015;(3):51-60. Russian.

19. Zakharova VP, Trembovetskaya TV, Savchuk TV, Batsak BV, Rudenko KV, Rudenko OV. [New aspects of the heart ventricular myocardium structure]. Heart and vessels. 2014;3:35-43. Russian. 


\section{Синдром лівобічної гіпоплазії серця: прогностичне значення морфологічних варіантів серця для визначення тактики лікування}

Захарова В. П. ${ }^{1}$, д-р мед. наук, ст. наук. співробітник, завідувач відділу патології з патологічною анатомією, https://orcid. org/0000-0003-3139-0366

Савчук Т. В. ${ }^{2}$, канд. мед. наук, доцент кафедри патологічної анатомії № 2, https://orcid.org/0000-0002-7218-0253

Труба я. П. ${ }^{1}$, канд. мед. наук, завідувач відділу хірургічного лікування вроджених вад серця у новонароджених та дітей молодшого віку, https://orcid.org/0000-0001-5214-408X

Лазоришинець В. В. ${ }^{1}$, академік НАМН України, д-р мед. наук, професор, директор, https://orcid.org/0000-0002-1748-561X

Руденко О. В. ${ }^{1}$, канд. мед. наук, провідний наук. співробітник відділу патології з патологічною анатомією, https://orcid. org/0000-0003-3640-566X

${ }^{1}$ ДУ «Національний інститут серцево-судинної хірургії імені М. М. Амосова НАМН України», м. Київ, Україна

${ }^{2}$ Національний медичний університет імені О. О. Богомольця, м. Київ, Україна

Резюме. Синдром лівобічної гіпоплазії серця (СЛГС) є однією з найскладніших вроджених вад серця з неминучим летальним результатом у разі природного перебігу захворювання. На сьогодні основними методами хірургічного лікування СЛГС $є$ багатоетапна операція Норвуда і фетальна аортальна вальвулопластика. Однак прогноз таких операцій часто буває непередбачуваним.

Мета: вивчити морфологічні варіанти лівого шлуночка при СЛГС і оцінити прогностичну значущість кожного з них при виборі хірургічної тактики.

Матеріали. Основна група - серця 63 новонароджених з СЛГС, група порівняння - серця 53 новонароджених без кардіопатології.

Методи. Оглядова мікроскопія, макро- і мікроморфометрія різних параметрів серця, визначення співвідношення їх абсолютних значень - індексів, статистична обробка даних.

Результати. За розміром і формою порожнини, товщиною стінки, наявності або відсутності фіброеластозу визначили 5 типів лівого шлуночка (ЛШ) при СЛГС: I - щілиноподібний гіпопластичний (n = 10; 15,9 \%); II - щілиноподібний гіпертрофічний (n = 19; 30,2 \%); III - циліндричний (n = 22; 34,9\%); IV - лакунарний (n = 6; 9,5 \%); $\mathrm{V}$ - лакунарний циліндричний $(\mathrm{n}=6 ; 9,5$ \%). У лівих шлуночках I типу значення «міжшлуночкового індексу» (співвідношення площ вільних стінок лівого і правого шлуночків на поперечних зрізах серця) були найменшими: 0,13 \pm 0,03 од. проти 1,96 \pm 0,31 од. у нормі. При II типі цей показник дорівнював 1,69 \pm 0,23 од.; при III - 1,59 \pm

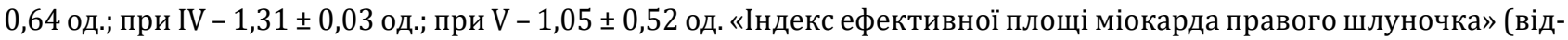
ношення площі вільної стінки правого шлуночка до суми площ вільної стінки і міжшлуночкової перегородки)

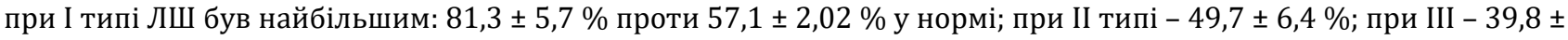

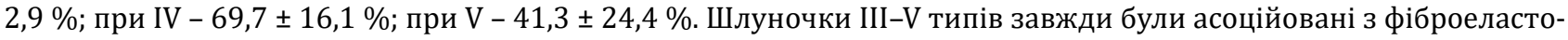
зом на відміну від I і ІІ типів.

Висновки. При СЛГС серця I типу є найбільш сприятливими для процедури Норвуда, тому що Лш через мінімальні свої розміри не є надмірним баластом для працюючого правого шлуночка. Ліві шлуночки II типу $є$ оптимальними для фетальної аортальної вальвулопластики, тому що протягом II-III триместрів гестації вони можуть включитися в систему кровообігу завдяки ремоделюванню. СЛГС із фіброеластозом ЛШ (III, IV, V Tипи) визначено найменш сприятливими як для пре-, так і для постнатальної хірургії, особливо за наявності фіброеластозу правого шлуночка.

Ключові слова: вроджені вади серця, синдром лівобічної гіпоплазії серця, морфологічні варіанти лівого шлуночка, варіанти клапанної патології, хірургічна тактика.

Стаття надійшла в редакцію 21.01.2021 р. 